Article

\title{
Environmental Performance of East Asia Summit Countries from the Perspective of Energy Security
}

\section{Yudha Prambudia * and Masaru Nakano}

Graduate School of System Design and Management, Keio University, Collaboration Complex, 4-1-1 Hiyoshi, Kohoku-ku, Yokohama, Kanagawa 223-8526, Japan; E-Mail: nakano@sdm.keio.ac.jp

* Author to whom correspondence should be addressed; E-Mail: prambudia.yudha@a6.keio.jp; Tel.: +81-45-564-2518; Fax: +81-45-562-3502.

Received: 21 September 2012; in revised form: 15 October 2012 / Accepted: 17 November 2012 / Published: 23 November 2012

\begin{abstract}
Energy security is an increasingly important issue for East Asia Summit (EAS) countries. The Cebu declaration on East Asia Energy Security provides a common ground towards improving energy security. However, EAS countries are in a different situation and face different challenges. This leads to varying policies in dealing with energy security. This study provides an analysis of future environmental performance of three EAS countries with distinct socioeconomic and energy conditions from an energy security standpoint. A model which captures complex interrelationships between different aspects of energy security is developed for the study. Aspects related to energy, socioeconomics, and the environment are considered in the model. Policy scenarios which reflect governments' efforts to improve energy security are developed for simulation. Analysis is performed by comparing each country performances indicated by measures related to $\mathrm{CO}_{2}$ emissions. The results show that Japan would achieve a very small increase in $\mathrm{CO}_{2}$ emission growth. China would still produce the largest amount of $\mathrm{CO}_{2}$ emission, but its growth would decrease significantly. In the contrary, Indonesia's emission would be the smallest, but its growth would be the fastest. The results indicate that Indonesia's commitment to the Cebu declaration goal will not be sustained. The study suggests that the Cebu declaration should be moved forward by including legally binding commitments and clear $\mathrm{CO}_{2}$ emission reduction targets.
\end{abstract}

Keywords: environmental performance; energy supply; energy security; policy; simulation 


\section{Introduction}

Energy security is closely related to environmental issues, such as climate change and global warming [1]. Certainly, policies directed to improve energy security will likely influence the environmental performance of a country, as measured by $\mathrm{CO}_{2}$ emissions, for example. In many concepts of energy security [2-4], energy availability is highly regarded, and is often considered the key issue. Thus, efforts to improve energy security are often based fundamentally on increasing energy supply. However, efforts to ensure energy supply may hinder environmental performance. Another important issue in this regard is energy consumption. Decreasing energy consumption by increasing efficiency is seen as another way to improve energy availability.

The issue of energy supply is extremely important for the EAS [5] countries because of the staggering growth in energy demand following their rapid economic development and the expanding production network in this region [6]. The Cebu declaration on East Asia energy security [4] exemplifies the importance of the issue of energy supplies for the EAS region and formulated a common perspective for improving it. However, EAS countries have different conditions from one another that are characterized by different energy markets and different stages of socioeconomic development. Considering these differences, efforts to ensure energy supply are expected to be guided by different goals and would therefore have different implications for environmental issues. With this in mind, this study aims to analyze the impact of energy policy options for improving energy security in the EAS countries, particularly insofar as these relate to pledged commitments on environmental matters, while considering the different characteristics of these countries.

The study selects China, Japan and Indonesia to represent three distinct country characteristics. In the East Asia Summit context, China's economy is the largest, whereas Japan is the most advanced country. China is the highest $\mathrm{CO}_{2}$ emitter from the developing economies of the region, whereas Japan is the highest emitter from the advanced economies of the region. Indonesia, on the other hand, is experiencing dynamic socioeconomic development which may direct its energy requirement to expose higher $\mathrm{CO}_{2}$ emission potential.

An integrated model was developed to simulate each country's future energy security. A key feature of the model is the feedback mechanism that is attributed to the interrelationships between different aspects of energy security. The representation of interrelationships in the model allows energy, socioeconomic and environmental sectors to be viewed as a unified interlocking system. In this regard, this approach to energy security evaluation is novel compared to other similar studies.

The paper is organized as follows: section two describes the characteristics of the countries; section three explains the model, the scenario developed for simulation, and the indicators used for measuring performance; section four presents the results and analyses; in section five, discussions on simulation results and challenges are presented; and, section six provides some concluding remarks. 


\section{The Characteristics of China, Japan and Indonesia}

To illustrate the different characteristics of China, Japan and Indonesia, their socioeconomic, energy and environmental conditions, as well as issues inherent to the three countries, are presented in this section. A summary of the characteristics is presented in Table 1.

Table 1. Summary of country characteristics.

\begin{tabular}{|c|c|c|c|c|c|c|c|c|}
\hline & \multicolumn{5}{|c|}{ Socioeconomics } & \multicolumn{2}{|c|}{ Energy } & \multirow{2}{*}{$\begin{array}{c}\text { Environment } \\
\mathrm{CO} 2 \\
\text { emission }\end{array}$} \\
\hline & $\begin{array}{c}\text { Pop } \\
\text { Number }\end{array}$ & $\begin{array}{c}\text { Pop } \\
\text { Growth }\end{array}$ & $\begin{array}{c}\text { GDP } \\
\text { /capita }\end{array}$ & $\begin{array}{c}\text { GDP-GDP } \\
\text { growth }\end{array}$ & $\begin{array}{c}\text { Tech } \\
\text { achievement }\end{array}$ & $\begin{array}{c}\text { Energy } \\
\text { consumption }\end{array}$ & $\begin{array}{l}\text { Energy } \\
\text { resource }\end{array}$ & \\
\hline China & Largest & Low & High & $\begin{array}{c}\text { Highest- } \\
\text { Slowing }\end{array}$ & $\begin{array}{c}\text { Adopter- } \\
\text { High }\end{array}$ & $\begin{array}{c}\text { Highest- } \\
\text { Accelerating }\end{array}$ & Abundant & Highest \\
\hline Japan & Large & Negative & Highest & Low-Stable & Leader & High-Stable & Scarce & High \\
\hline Indonesia & Large & High & Low & $\begin{array}{c}\text { High- } \\
\text { Accelerating }\end{array}$ & $\begin{array}{c}\text { Adopter- } \\
\text { Low }\end{array}$ & $\begin{array}{c}\text { Modest- } \\
\text { Accelerating }\end{array}$ & Abundant & Low \\
\hline
\end{tabular}

\subsection{China}

With more than 1.3 billion people, China's population is the largest in the world, although its population growth is now slowing, decreasing from $1.45 \%$ in 1990 to $0.51 \%$ in 2009 [7]. China's economy developed very rapidly from 1999 to 2007 , with GDP growth at $9.6 \%$ in 1999 to $14.7 \%$ in 2007; however, this growth has slowed to an average of 9.7\% from 2008 to 2010 [8] and, in 2011, the growth is at 9.2\% [9]. China's GDP per capita is 4,878 USD (2000 at PPP) [9]. In 2002, China's technological achievement ranked 47th and improved to 41st in 2009 [10].

Along with rapid economic development, China's energy consumption is also quickly increasing. China's primary energy consumption more than doubled from 777 MTOE in 1998 to 1.866 MTOE in 2008 [11]. Although China has substantial oil resources, in 1993, it became a net importer of oil and ranked as one of the largest oil importers in the world in 2000 [12]. China's energy mix is dominated by coal, which is also the main reason for China's substantial $\mathrm{CO}_{2}$ emissions. Coal production doubled from 2002 to 2008 from 727 MTOE to 1471 MTOE [11], and China's coal consumption accounted for more than $80 \%$ of its $\mathrm{CO}_{2}$ emission in 2009 [13]. Considering the large coal reserves China possesses, it is expected that coal will continue to play a significant role in China's energy profile.

China's $\mathrm{CO}_{2}$ emission is concerning for the East Asia region and for the world. International pressure on China to improve its environmental performance is constant. China must attempt to balance its economic growth with reduction of its abundant $\mathrm{CO}_{2}$ emissions.

\subsection{Japan}

Japan is the most advanced economy in this region. Its GDP per capita in 2008 is 28,172 USD (2000 at PPP) [9]. This is almost six times that of China and nine times that of Indonesia. However, the growth is less dynamic. Japan's GDP growth from 1998 to 2008 in average was 0.96\% [7]. Japan's population is aging and decreasing. From 1990 to 2009, the proportion of people aged more than 65 increased from $12 \%$ to $23 \%$; people aged 15 to 64 years old decreased from $70 \%$ to $64 \%$; and, people below 15 years old also decreased from $18 \%$ to $14 \%$ [14]. The annual population growth 
declined from $0.24 \%$ in 2001 to $-0.11 \%$ in 2009 [7] (ADB, 2010). Technological achievement of Japan has been very high and ranked 5th in both 2002 and 2009 [10].

Japan's primary energy consumption is the second largest in the region. However, its growth is almost idle. From 2000 to 2008, it has been steady at an average of $351.8 \mathrm{MTOE} /$ year [11]. The $\mathrm{CO}_{2}$ emission related to energy use has been steady at an average of 1226 million tons (Mton) $\mathrm{CO}_{2}$ from 2000 to 2007. However, it is now declining from its 1098 Mton- $\mathrm{CO}_{2}$ in 2009 [13]. However, due to the Fukushima accident, Japan's $\mathrm{CO}_{2}$ emission in 2011 was accelerating. Compared to the other two countries, Japan's fossil energy resources are extremely limited. Historically, it has been an energy importer country; it is importing almost $99 \%$ of its oil, $98 \%$ of its coal, and $96 \%$ of its gas [11]. Oil has been the dominating primary energy, followed by coal and gas in second and third [11].

Japan's efficiency in using energy, which is driven by the scarcity of fossil energy, is very high. The efficiency contributes significantly to Japan's environmental performance. Nevertheless, its $\mathrm{CO}_{2}$ emission is the highest among advanced economies in the East Asia region. As the most advanced economy in the region, Japan is obliged to become a leader in environmental performance and inspire the neighboring developing economies.

\subsection{Indonesia}

Since 1998's economic crisis, Indonesia's economy has been growing confidently. With an annual GDP growth of $6.1 \%$ from 2009-2010 [15], the government is confident that future economic development will continue. The GDP per capita is at 3,263 USD (2000 at PPP) [9]. The population growth of Indonesia has been modest for the last decade [16], although the 2010 census result showed $1.49 \%$ annual growth, which was $14 \%$ higher than predicted [15]. Indonesia's population is expected to continue to grow. Its technological achievement in 2001 and 2002 is in the lower part of the technology adopter category, ranking 60th overall [10,17].

Indonesia's energy demand is increasing and follows its economic growth. The average energy consumption growth increased from $9.2 \%$ in $2000-2005$ to $12.1 \%$ in $2005-2008$ [18]. Oil is the dominant energy source for Indonesia; however, its role is decreasing while coal and gas consumption are increasing. The increasing growth in coal utilization is noticeably important because of concerns over its environmental impact, such as $\mathrm{CO}_{2}$ emissions. Indonesia's $\mathrm{CO}_{2}$ emissions worsened over the last decade. The average annual $\mathrm{CO}_{2}$ emission from 1999 to 2004 was $11.2 \mathrm{Mton}-\mathrm{CO}_{2} /$ year; from 2005 to 2009 , that amount increased to $21.1 \mathrm{Mton}-\mathrm{CO}_{2} /$ year [13].

Indonesia is traditionally an energy exporter; however, oil production has declined over the last decade [18]. This eventually forced Indonesia to leave OPEC in 2008 because it became a net oil importer. On the other hand, coal production has increased significantly in recent years, but most of it is exported. Simultaneously, gas production has been gradually increasing over the years but long-term contracts will hinder the supply of domestic gas [18].

Indonesia is currently enjoying a favorable economic growth. Threatened by the risk of not having sufficient energy for its economic growth, it is likely that Indonesia will search for the easiest way to lessen the risk. This may lead Indonesia to ignore environmental concerns and utilize its abundant fossil energy resources. 


\section{Simulation Model}

An integrated energy security simulation model has been developed for policy scenario simulation. Recent studies $[19,20]$ view energy security as a multidimensional issue that requires a comprehensive framework to evaluate. Comprehensive energy security evaluation is characterized by utilization of a multitude of indicators. An implementation of such an evaluation framework can be found in [21]. Nonetheless, many of the indicators are interrelated $[19,20]$. Although this characteristic is acknowledged by the studies, it has not yet been operationalized in a comprehensive energy security evaluation. This shortcoming hinders the reliable conduct of ex-ante evaluations because changes in one indicator are not necessarily relevant for the others. In light of this, a model that can capture the interrelationships between energy security indicators and energy security dimensions, to a larger extent, would be a step forward for evaluating energy security.

The simulation model in this study is mainly based on the work of Prambudia et al. [22] as a starting point. For this study, their model has been modified and extended to allow broader analyses. The configuration of the original model was modified by adding and removing variables and adding and removing relations between the variables, to develop a model that can describe the conditions of both China and Japan. For example, for Japan's model, the nuclear capacity variable is added while the natural gas export variable is removed. The model was also extended by adding variables relevant to environmental issues, and the model may therefore be used to investigate the environmental aspect of energy security. The Indonesian model, in particular, has been modeled in more detail because of easier access to experts and data.

Two types of scenarios are developed in the model. First, a Business-as-Usual (BAU) scenario is developed and simulated to examine the outcome of the continuation of existing energy development policies for energy security. Second, an Alternative Development Scenario (ADS) is developed and simulated. The alternative scenarios introduce different pathways of energy development for each country model. Policy analysis is performed by comparing the results of these two types of scenarios.

\subsection{Model}

The model is broadly segregated into three sectors, namely, energy, socioeconomics and environment. From an aggregated point of view, the model mechanism is characterized by feedback loops between the sectors. The conceptual framework of the model is presented in Figure 1.

In the following sections, a general description of the model, and various scenarios and indicators to measure environmental performance are elaborated. 
Figure 1. Conceptual framework of the model.

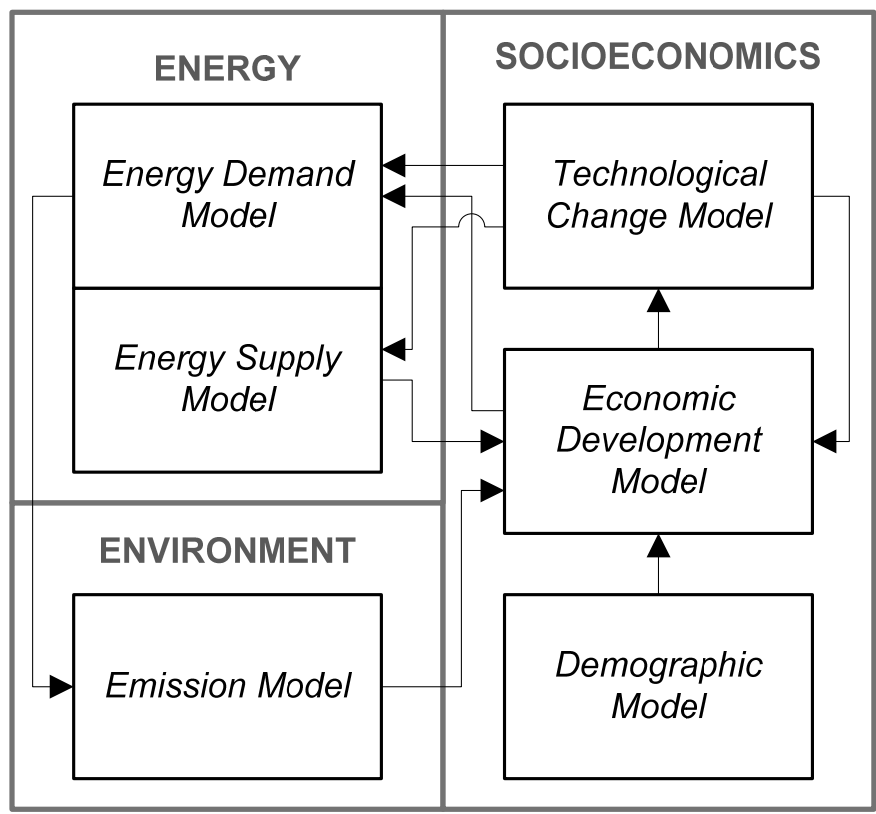

\subsubsection{Structure}

\subsubsection{Energy Sector}

The energy sector is central for the model. This sector is composed of an energy supply and energy demand model. Each type of energy source considered in this study (oil, gas, coal, hydro, geothermal, biomass, waste, wind, solar, and nuclear) is represented in this two-model framework. In the case where a certain part of the framework is not applicable (i.e., the energy trade submodel for geothermal), it will not be applied.

The energy supply model consists of an energy trade submodel and energy production submodels. The energy trade submodel allows for the influences of the dynamics of energy import and export on energy supply to be considered. The energy production submodel influences energy supply by energy production taking into account energy production performance and the dynamics of the energy reserve level. The energy demand model consists of five energy consumption sectors assembled within the energy consumption submodel: household, industry, transport, commercial, and other.

\subsubsection{Socioeconomic Sector}

This sector is composed of the demographic, economic development and technological change models. In the demographic model, the variable determining the population is exogenous. It is calculated using a nonlinear equation derived from the country's historical population data. Economic development is indicated by Gross Domestic Product (GDP). GDP is calculated as a summation of all economic value added (VA) from the VA submodel, according to the International Standard Industrial Classification (ISIC) of all economic activities [23]. The VA submodel is influenced by the Technology Advance index. GDP per capita is calculated as a division of GDP by Population. Technological change is calculated by adopting the Technological Advance index of UNIDO [24]. 


\subsubsection{Environmental Sector}

The environmental sector consists of an emissions model that is composed of $\mathrm{CO}_{2}$ emissions and the $\mathrm{CO}_{2}$ tax submodel. The $\mathrm{CO}_{2}$ emission submodel calculates the level of $\mathrm{CO}_{2}$ inventory by considering $\mathrm{CO}_{2}$ emission from fossil energy consumption. The $\mathrm{CO}_{2} 2$ tax submodel calculates the effect of the $\mathrm{CO}_{2}$ tax on economic growth. The $\mathrm{CO}_{2}$ tax submodel is the key element connecting the environmental sector to the socioeconomic sector and constructing the model as a unified complex system model.

\subsubsection{Feedback Loop}

\subsubsection{Energy Supply_Economic Development_-Technological Change Loop}

The energy sector influences the socioeconomic sector through energy supply. An increase in energy supply does not necessarily mean an increase in GDP, but it decreases the chance of disruption by energy shortage and therefore allows the GDP to grow. In addition, a surplus of energy production contributes to the GDP growth of exporters. The GDP positively influences the advancement of technology, therefore, an increase in GDP may accelerate technological change. In turn, technology advances positively influence energy supply. The level of technology positively influences energy supply by making the renewable energy supply more viable. This loop is a reinforcing feedback loop.

\subsubsection{Energy Demand-Emission-Economic Development-Technological Change Loop}

The energy sector influences the environmental sector through energy consumption. $\mathrm{CO}_{2}$ emissions are positively influenced by energy consumption. An increase in energy consumption will cause $\mathrm{CO}_{2}$ emissions from energy use to increase, as well. Subsequently, $\mathrm{CO}_{2}$ emissions are assumed to have a negative impact on economic growth, potentially reducing GDP. GDP positively influences the advancement of technology, therefore, increases in GDP may accelerate technological advances. In turn, technological advances influence energy consumption negatively because technological advances are assumed to bring more efficiency to energy consumption. Finally, energy consumption positively influences $\mathrm{CO}_{2}$ emissions; a decrease in energy consumption will decrease $\mathrm{CO}_{2}$ emissions. This loop is a balancing feedback loop.

\subsubsection{Energy Demand—Emission—Economic Development Loop}

The energy demand sector positively influences $\mathrm{CO}_{2}$ emissions through energy consumption. Subsequently, $\mathrm{CO}_{2}$ emissions are assumed to have a negative impact on economic growth, thus reducing GDP. In turn, however, GDP positively influences energy consumption because an increase in GDP will induce energy consumption. This loop is a balancing feedback loop. 


\subsubsection{Technological Change-Economic Development Loop}

Technological change is assumed to be influenced positively by GDP because an increase of GDP will result in faster technological advancement. In turn, technological advances have a positive influence on the GDP. Therefore, faster technological advancement will hasten economic growth. This is a reinforcing feedback loop.

\subsubsection{Parameters}

The following demarcates parameters provided in the model which allow simulation of scenarios in this study:

- Energy efficiency level. This parameter is provided for each energy consumption sector. This parameter is influenced by the Technology Advance variable. It allows simulation of higher or lower effects of technological advancement to energy consumption. It can be used to simulate energy efficient technology adoption by, for example, energy labeling and standards policies. The value of this parameter is set to 1 at year 2008 .

- Solar, wind, microhydro and biomass growth factor. This parameter allows higher or lower production growth of each renewable energy. It can be used to simulate, for example, rapid introduction of renewable energy policy. The value of this parameter is set to 1 at year 2008 .

- Geothermal and hydro capacity growth factor. This parameter allows higher or lower capacity factor growth along with its capacity factor. It can be used to simulate changes in capacity factors of new and existing large plants. The value of this parameter is set to 1 at year 2008 .

- Fossil energy consumption growth factor. This parameter is provided for each type of fossil energy. It allows higher or lower fossil consumption growth along with the Energy Efficiency level influence. It can be used to simulate structural changes in fossil energy utilization, for example, kerosene-to-gas switching policy. The value of this parameter is set to 1 at year 2008 .

- Nuclear energy capacity growth factor. This parameter allows higher or lower nuclear energy capacity along with its capacity factor. It can be used to simulate nuclear expansion policy. The value of this parameter is set to 1 for the year 2008 .

- Coal $\mathrm{CO}_{2}$ efficacy level. This parameter allows changes to the level of $\mathrm{CO}_{2}$ emission from coal. It can be used to simulate clean technology implementation such as the Integrated Gasification Combine Cycle (IGCC) and Carbon Capture and Storage (CSS) technologies. The value of this parameter is between $0 \%$ and $100 \%$.

- Energy trade limits. This parameter allows limitation on energy trade to be considered in the model. It can be used to simulate policy on energy trade, such as energy import/export ban. The parameter value can be expressed by using physical amount of energy (i.e. MTOE) or share of energy from other variable (i.e. percentage of energy production).

- $\mathrm{CO}_{2}$ tax implementation. This parameter functions as a lever to simulate the implementation of a $\mathrm{CO}_{2}$ tax. It allows a predetermined effect of $\mathrm{CO}_{2}$ tax on economic growth to be considered in the simulation. It is assumed that a $\mathrm{CO}_{2}$ tax rate will increase incrementally in proportion to the $\mathrm{CO}_{2}$ emission rate. Should $\mathrm{CO}_{2}$ emissions hold or be reduced to below the level of the 
previous year, the $\mathrm{CO}_{2}$ tax rate is considered to be unchanged from the previous year. The parameter value is either on or off.

\subsubsection{Data}

Energy data has been primarily obtained from the Institute of Energy Economics Japan energy database. In the case of data unavailability, the data are estimated. For Indonesia, some energy data are combined with national energy data to improve accuracy. Economic data in terms of economic value added in U.S. dollars are collected from the United Nations Statistical Division and are used in this study to construct the GDP. The value added is at the current price in U.S. Dollars. The population data are from the UN Population Division. The $\mathrm{CO}_{2}$ emissions data have been obtained from the Energy Information Administration of the U.S. government.

\subsection{Scenario}

In BAU scenario, it is assumed that development pathway is a result of a continuation of policies that were implemented before 2011 (based on the most recent available data). It is also assumed in the BAU scenario that there will be no policy intervention within the simulation period. Conversely, the ADS considers policies introduced during and after 2011. The summaries of the ADS scenario are presented in Table 2 .

Table 2. Alternative Development Scenarios.

\begin{tabular}{|c|c|c|c|}
\hline Sector & China & Japan & Indonesia \\
\hline Oil & Follows BAU & Follows BAU & Follows BAU \\
\hline Coal & No cap for coal utilization. & $\begin{array}{l}\text { Coal consumption increases } \\
30 \% \text { by } 2020 \text { and } 50 \% \text { by } \\
2030 \text {. CO } 2 \text { emission from } \\
\text { newly built IGCC/CSS } \\
\text { plants are } 90 \% \text { lower. }\end{array}$ & $\begin{array}{l}25 \% \text { of coal production for } \\
\text { domestic supply. Coal } \\
\text { consumption growth is } \\
\text { increasing gradually } 5 \% \text { per } \\
\text { year. }\end{array}$ \\
\hline Gas & Follows BAU & $\begin{array}{l}\text { Gas consumption increases } \\
40 \% \text { by } 2020 \text { and } 60 \% \text { by } \\
2030 .\end{array}$ & $\begin{array}{l}\text { New contract of long-term gas } \\
\text { export is banned. Surplus of gas } \\
\text { production is directed to } \\
\text { domestic market. }\end{array}$ \\
\hline Nuclear & $\begin{array}{l}\text { Nuclear power capacity is } \\
\text { increased to } 43 \mathrm{GW} \text { by } 2025 \text {. }\end{array}$ & $\begin{array}{l}\text { By } 2030, \text { Nuclear power } \\
\text { capacity will be at } 30 \% \text { of } \\
2010 \text { capacity. }\end{array}$ & Follows BAU \\
\hline Geothermal & $\begin{array}{l}\text { Geothermal energy use } \\
\text { increase to } 69 \text { mtce by } 2015 \text {. } \\
\text { The growth will continue to } \\
2025 \text {. }\end{array}$ & $\begin{array}{l}\text { Geothermal power capacity } \\
\text { is increased to } 3.4 \mathrm{GW} \text { by } \\
2020\end{array}$ & $\begin{array}{l}\text { Geothermal capacity increases } \\
20 \% \text { by } 2020 \text { and } 40 \% \text { by } 2030 \text {. } \\
\text { Geothermal energy growth is } \\
\text { increasing accordingly in } 2025\end{array}$ \\
\hline Solar & $\begin{array}{l}\text { Solar power capacity is } \\
\text { expanded to } 10 \mathrm{GW} \text { by } 2015 \\
\text { and } 50 \mathrm{GW} \text { by } 2020 \text {. The } \\
\text { growth will continue to } 2025 \text {. }\end{array}$ & $\begin{array}{l}\text { Solar power capacity is } \\
\text { increased to } 81 \mathrm{GW} \text { in } 2020 .\end{array}$ & Follows BAU \\
\hline Wind & $\begin{array}{l}\text { Wind power capacity is } \\
\text { increased to } 100 \mathrm{GW} \text { in } 2015 \text {. } \\
\text { The growth will continue to } \\
2025 \text {. }\end{array}$ & $\begin{array}{l}\text { Wind power capacity is } \\
\text { increased to } 40 \mathrm{GW} \text { by } 2020 \text {. }\end{array}$ & Follows BAU \\
\hline
\end{tabular}


Table 2. Cont.

\begin{tabular}{|c|c|c|c|}
\hline Hydro & $\begin{array}{l}\text { Hydro power capacity is } \\
\text { expanded to } 325 \text { GW by } 2015 \\
\text { from } 197 \text { GW in } 2009 \text {, the } \\
\text { capacity is increasing } \\
\text { accordingly, with capacity } \\
\text { factor increase to } 60 \% \text { by } \\
2025 \text {. }\end{array}$ & Follows BAU & $\begin{array}{l}\text { Hydro (Micro) power capacity is } \\
\text { increasing at } 5 \% \text { per year. }\end{array}$ \\
\hline Biomass & $\begin{array}{l}\text { Biomass power capacity is } \\
\text { increased to } 13 \mathrm{GW} \text { by } 2015 \text {. } \\
\text { The growth will continue to } \\
2025 \text {. }\end{array}$ & Follows BAU & $\begin{array}{l}\text { Biomass utilization is increasing } \\
5 \% \text { per year }\end{array}$ \\
\hline Efficiency & $\begin{array}{l}35 \% \text { efficiency increase in } \\
\text { transport sector by } 2025 \text {. }\end{array}$ & $\begin{array}{l}30 \% \text { increase of efficiency } \\
\text { by } 2020 \text { and } 40 \% \text { by } 2030 \\
\text { in household and } \\
\text { commercial sectors. } 20 \% \\
\text { efficiency increase by } 2020 \\
\text { and } 50 \% \text { by } 2030 \text { in the } \\
\text { transportation sector. }\end{array}$ & $\begin{array}{l}30 \% \text { increase of energy } \\
\text { efficiency in household and } \\
\text { commercial by } 2030 .\end{array}$ \\
\hline $\begin{array}{l}\text { Carbon } \\
\text { Tax }\end{array}$ & $\begin{array}{l}\text { Carbon tax rate is } \\
\text { implemented from } 2009 \text { at } 20 \\
\text { yuan/ton-CO2. }\end{array}$ & $\begin{array}{l}\text { Carbon tax rate at } 2.400 \\
\text { Yen/ton-CO2 is } \\
\text { implemented from } 2009 .\end{array}$ & $\begin{array}{l}\text { Gradually increasing CO2 tax of } \\
\text { Rp. } 80,000 / \text { ton-CO2 to } \\
\text { Rp. } 280,000 / \text { ton-CO2 is } \\
\text { implemented from } 2009 \text { to } 2025\end{array}$ \\
\hline
\end{tabular}

\subsubsection{Scenario for China}

China's energy policy is expressed in National Action plans that are renewed every five years. The latest is the 12th Five-Year Plan on March 2011. The plan marked a turning point on China's priorities as it indicates China's emphasis on sustainable growth. It mentioned a target of $17 \%$ decrease in $\mathrm{CO}_{2}$ emission per unit of GDP in 2015. Three strategic investment areas related to energy are: renewable and clean energy, energy conservation and environmental protection, and clean energy vehicles [25]. China's scenario is developed based on the plan.

- Renewable energy:

- The plan calls for hydropower development in southwest China. In total, hydropower capacity will be expanded from $197 \mathrm{GW}$ in 2009 to $325 \mathrm{GW}$ by 2015 . Based on this, this study assumes that hydropower capacity will increase accordingly and therefore shows a capacity factor increase from $37 \%$ in 2009 to $60 \%$ by 2025 .

- The installed solar power capacity will be expanded from $300 \mathrm{MW}$ in 2010 to $10 \mathrm{GW}$ by 2015 and $50 \mathrm{GW}$ by 2020 . Following this target, this study assumes that solar energy growth is increasing accordingly and that such growth will stabilize by 2025 .

o Wind power capacity is targeted to increase from $41.8 \mathrm{GW}$ in 2010 to $100 \mathrm{GW}$ in 2015 . Wind power generation is planned to reach 190 billion KWh annually. This study assumes that growth will continue until 2025.

- Geothermal energy surveys and exploration campaigns to map available and economically viable geothermal resources are underway. The declared aim is to use geothermal power equal to approximately 69 million tons of coal by 2015 , which equals $3.678 \mathrm{GW}$ at a $39 \%$ capacity factor. This study assumes that such growth will continue until 2025. 
- China plans to expand its installed generation capacity for biomass power from $5.5 \mathrm{GW}$ in 2010 to $13 \mathrm{GW}$ in 2015 by producing 5 billion tons of biomass power every year. Following this, this study assumes that biomass production will increase accordingly to meet this target and that such growth will continue until 2025.

- Nuclear power: China plans to construct 10 new nuclear power plants and increase its nuclear capacity to $43 \mathrm{GW}$ by 2015 . The Fukushima incident may have some influence over the plan. However, it is uncertain to what extent. It is assumed in this study that the capacity expansion plan will be delayed until 2025.

- Fossil energy: Plan to cap coal utilization at 3.8 billion tons of coal by 2015 is mentioned in the plan. Capping coal utilization is a very daunting target, considering China's dependence on this energy source. Therefore, we dismiss this policy and assume that there will be no effective capping target.

- Energy efficiency and conservation: Clean energy vehicles are targeted to reach the market at 500,000 units annually. China is expecting 15 million hybrid and electric vehicles in the market by 2020 , which is $88 \%$ of the current vehicle market. Following this, the study assumed that the effect of the plan is to increase efficiency in the transport sector by $35 \%$ in 2025.

- Carbon tax: Following a study of dynamic $\mathrm{CO}_{2}$ effects on China's economy [26], it is assumed that the carbon tax rate will be implemented at 200 yuan/ton- $\mathrm{CO}_{2}$ from 2009. The loss of GDP due to this level of $\mathrm{CO}_{2}$ tax rate is at $1 \%$.

\subsubsection{Scenario for Japan}

In 2010, a new revision of Japan's national energy plan was announced [27]. However, the great Japan earthquake will require changes in the plan. There are still uncertainties and debates on Japan's energy policy after the earthquake, though policy directions such as [28] are proposed in this regard. Based on these considerations, the following scenario has been developed.

- Renewable energy: In the wake of the nuclear crisis, renewable energy introduction will be rigorously expanded.

- With the target of 12 million houses of PV installation and total target of $81 \mathrm{GW}$ in 2020, it is assumed that solar PV implementation growth will increase accordingly from 2011 level.

- Wind power development is targeted to increase. Wind power capacity is targeted up to $40 \mathrm{GW}$ by 2020 . However, the growth is still hampered by challenges such as site restriction and interconnection issues. The study assumed that the development is slowed and the target will be achieved in 2040, thus the growth is increasing accordingly.

- Geothermal power capacity is targeted to increase to its maximum potential at $3.4 \mathrm{GW}$ by 2030 . However, there are conflicts of interest with national parks and hot springs which are withholding the development. It is assumed that the target will be achieved by 2040 , thus the geothermal energy growth is increasing accordingly. 
- Nuclear: Nuclear power capacity is planned to be expanded to $68 \mathrm{GW}$ by building 9 new nuclear reactors by 2020 with $85 \%$ utilization rate and totally 14 reactors by 2030 , with facility utilization rate at $90 \%$. However, the Fukushima accident affects the expansion plan significantly. During 2011-2012, almost all of Japan's nuclear power plants are shut down without certainty of when to be started again as Japan is considering a phased-out nuclear program. However, stable supply of electricity may not be possible without nuclear energy [28]. Therefore, this scenario assumes that the nuclear phase-out program will be implemented and that the phase-out will happen at a much slower rate. Moreover, the nuclear power will continue to be generated in Japan at a reduced rate, but with more emphasis on efforts to ensure safety. Therefore, it is assumed in this study that by 2030, nuclear power capacity will be at $30 \%$ of pre-Fukushima operating capacity.

- Advance utilization of fossil fuel: Coal consumption will increase as new coal power plants with IGCC (Integrated Gasification Combine Cycle) standard will be available by 2020 . In addition, commercialization of CCS (Carbon Capture and Storage) within 2020 will further encourage coal consumption. The Fukushima crisis has also pushed a rise in coal consumption, in an attempt to balance the lost nuclear generation capacity. It is assumed that coal consumption growth will increase to $30 \%$ by 2020 and $50 \%$ by 2030 . However, the $\mathrm{CO}_{2}$ emission from new plants with IGCC/CCS implementation will be $80 \%-90 \%$ less [29]. It is assumed in this scenario that from 2020 on, $\mathrm{CO}_{2}$ emissions from coal power plants will be $90 \%$ lower.

- Natural gas: The Fukushima crisis is also affecting gas consumption, that is, causing an increase in gas utilization. Therefore, the scenario assumed that gas consumption will increase $40 \%$ by 2020 and $60 \%$ by 2030 .

- Energy efficiency: Household sector efficiency will improve by introduction of highly efficient hot water supply devices. By $2030,80 \%$ to $90 \%$ of households will be using the devices. In addition, efficient lighting, i.e. LED will be diffused $100 \%$ by 2030 . The commercial sector will conserve more energy by diffusion of more efficient IT equipment, which will be fully adopted by 2020 . The effect of this on primary energy consumption is assumed at $30 \%$ by 2020 and $40 \%$ at 2030 . The transportation sector will gain more efficiency by mobilizing all possible policy measures (i.e. fuel efficiency and battery standard) to increase the share of the next generations vehicles in new vehicle sales. It is assumed that fossil energy consumption from this sector will decrease accordingly up to $20 \%$ by 2020 and up to $50 \%$ by 2030 .

- Carbon tax: Implementation of a carbon tax in Japan will have only a very small effect on Japan's GDP with a carbon tax rate at JPY2400/ton- $\mathrm{CO}_{2}$, which is as low as $-0.01 \%$ [30] and is the rate assumed in this study.

\subsubsection{Scenario for Indonesia}

Currently, Indonesia has significant concerns about its energy supply. The Peraturan President (President's Regulation) no. 5/2006 regarding National Energy Policy, emphasizes the importance of energy availability for energy security, as was further expressed in 2007 in the Blueprint Pengelolaan Energi Nasional (Blueprint of National Energy Management) 2006-2025, and other ministerial 
regulations [31-34] concerning energy policy. Guided by the documents, the scenario for Indonesia is developed as follows:

- Renewable energy: Rencana induk pengembangan energi baru dan terbarukan (New and renewable energy development master plan), also known as RIPEBAT [32], covering nonfossil energy production technology and market development, has recently been revised. In particular, the government has focused more on development of the biomass, geothermal and microhydro energy market. In this scenario, biomass utilization is assumed to increase gradually at an annual rate of 5\%; microhydro capacity is assumed to increase at the same rate of 5\% per year; and, geothermal capacity will increase $20 \%$ by 2020 and $40 \%$ by 2030 .

- Nuclear power: There have been many forums and discussions about nuclear power development plans for Indonesia. The government has been planning nuclear power development since 1956 [35]. However, the plan has yet to be realized because of strong public opposition. The recent Fukushima crisis made this resistance stronger. Therefore, this scenario assumes that nuclear power will not be available during the simulation period for Indonesia.

- Fossil energy: A strong policy in the coal and gas sector has been undertaken that prioritizes fulfillment of domestic demand. Ministerial regulations controlling coal and gas exports were recently announced in 2011. These regulations stated that the government will determine a minimum percentage of coal to be allocated for the domestic market annually. The regulations also introduced restrictions to new gas export contracts. This scenario assumes that a minimum of $25 \%$ of Indonesian coal production is reserved for domestic demand. Following this development, this study assumes that coal consumption will grow at rate of $5 \%$ per year. Gas exports, beginning in 2011, will be assumed to be constant at $40.15 \mathrm{MTOE} /$ year because no new long-term contracts will be signed. A modest increase in gas consumption is assumed at $2 \%$ per year. There are no new developments with respect to oil; thus, the scenario assumes that oil development will follow trends in the historical data. However, this study assumes that there will be some substitution between oil and other energy sources, so that the development of other energy sources will contribute negatively to oil consumption.

- Energy efficiency and conservation: Rencana Induk Konservasi Energy Nasional (National Energy Conservation Master Plan), or RIKEN, was introduced in 2005 [32]. Currently, RIKEN is implemented mainly by establishing energy performance standards and labeling schemes. This scenario assumes that RIKEN will encourage more efficient technology to be adopted more rapidly and that higher efficiency goals will be realized. Thus, higher efficiencies of up to $30 \%$ will be gained by 2030 in commercial and household energy consumption as standards and labeling on buildings and appliances become more fully effective.

- Carbon tax: The Ministry of Finance proposed a plan for full carbon tax implementation in 2020 [36]. According to Yusuf and Resosudarmo [37], carbon tax implementation may inflict little damage to Indonesia's GDP because of its distributional effect. A carbon tax rate of Rp.280,000/ton- $\mathrm{CO}_{2}$ may decrease Indonesia's GDP as much as $0.04 \%$. This study assumes that the rate is implemented gradually from Rp.80,000/ton- $\mathrm{CO}_{2}$ to $\mathrm{Rp} \cdot 280,000 /$ ton- $-\mathrm{CO}_{2}$, beginning in 2010 . 


\subsection{Indicator}

In order to measure the dynamics of energy security in terms of environmental performance, this study employed some indicators relevant to $\mathrm{CO}_{2}$ emission, as suggested in [38-40]. In the following section, the indicators are explained.

\subsection{1. $\mathrm{CO}_{2}$ Emission}

This indicator shows the amount of $\mathrm{CO}_{2}$ emission from energy use. It is calculated as a function of fossil energy consumption. It can be expressed as the following equation:

$$
C_{e m}=\alpha \cdot C_{o}+\beta \cdot C_{g}+\gamma \cdot C_{c}
$$

where $C_{e m}$ is $\mathrm{CO}_{2}$ emission in Ton- $\mathrm{CO}_{2} . C_{o, g, c}$ is, respectively, oil, gas and coal consumption, all in million tons of oil equivalent (MTOE). $\alpha, \beta$ and $\gamma$ are respectively $\mathrm{CO}_{2}$ emission coefficient of oil, gas and coal consumption. A lower value for this indicator is better.

The rate of $\mathrm{CO}_{2}$ emissions is a primary factor in measuring environmental performance. However, by itself, this factor does not indicate much about a country's performance. To be more meaningful, it needs to be combined with other factors. In this study, it is combined with factors from the socioeconomic and energy sectors, as explained below.

\subsubsection{Carbon Intensity of Economy}

This indicator is defined as the ratio between $\mathrm{CO}_{2}$ emission and economic development. It indicates the amount of $\mathrm{CO}_{2}$ emitted in order to produce one unit of GDP. The indicator can be expressed as follows:

$$
E C_{e m}=\frac{C_{e m}}{G D P}
$$

where $E C_{e m}$ is carbon intensity of economy, Cem is $\mathrm{CO}_{2}$ emission and GDP is GDP in U.S. dollars. The lower the value of this indicator, the better.

\subsubsection{Per Capita $\mathrm{CO}_{2}$ Emission}

This indicator is defined as the ratio between $\mathrm{CO}_{2}$ emission and population size. It indicates the amount of $\mathrm{CO}_{2}$ emitted by a person. It can be expressed as follows:

$$
C A P C_{e m}=\frac{C_{e m}}{P}
$$

where $C A P C_{e m}$ is per capita $\mathrm{CO}_{2}$ emission, $C_{e m}$ is $\mathrm{CO}_{2}$ emission and $P$ is population. The lower the value of this indicator is better.

\subsubsection{Carbon Intensity of Energy}

This indicator is defined as the ratio between $\mathrm{CO}_{2}$ emission and total primary energy consumption. It indicates the amount of $\mathrm{CO}_{2}$ emitted for every unit of energy consumed. It can be expressed as follows: 


$$
C C_{e m}=\frac{C_{e m}}{T P E C}
$$

where $C C_{e m}$ is carbon intensity from energy consumption, $C_{e m}$ is $\mathrm{CO}_{2}$ emission and TPEC is the total primary energy consumption in TOE (Ton Oil Equivalent). A lower value of this indicator is better.

\section{Result and Analysis}

The scenarios are analyzed based on indicators from environmental aspects of energy security. The dynamics of individual country indicators are presented followed by country comparisons of each indicator.

\subsection{Country Performance}

\subsubsection{China}

In both BAU and ADS scenarios, China's emission will increase, but its rate is slowing down. In the BAU scenario, $\mathrm{CO}_{2}$ emission will reach up to $12,244 \mathrm{Mton}-\mathrm{CO}_{2}$ by 2025 from $7948 \mathrm{Mton}-\mathrm{CO}_{2}$ in 2010. The ADS scenario produces lower $\mathrm{CO}_{2}$ emission with 11,231 Mton- $\mathrm{CO}_{2}$ in 2025. Figure 2 shows the $\mathrm{CO}_{2}$ emission of China.

Figure 2. China's $\mathrm{CO}_{2}$ emission.

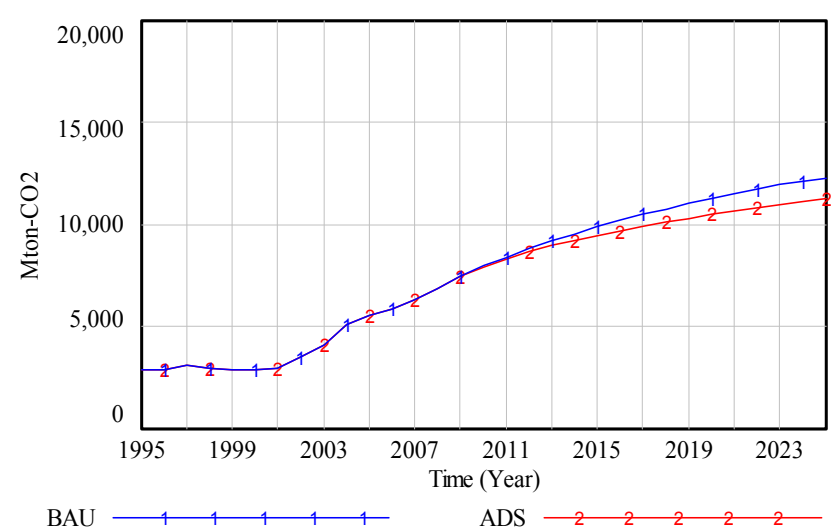

In both scenarios, China's carbon intensity of economy is decreasing. Its carbon intensity of economy in the BAU scenario would be at $0.70 \mathrm{Kg}_{-} \mathrm{CO}_{2} / \mathrm{USD}$ in 2025 . The ADS scenario produces slightly higher carbon intensity of economy at $0.77 \mathrm{Kg}-\mathrm{CO}_{2} / \mathrm{USD}$ in the same year. In this regard, China's performance in the ADS scenario is worse than BAU scenario. Figure 3 shows China's carbon intensity of economy. 
Figure 3. China's carbon intensity of economy.

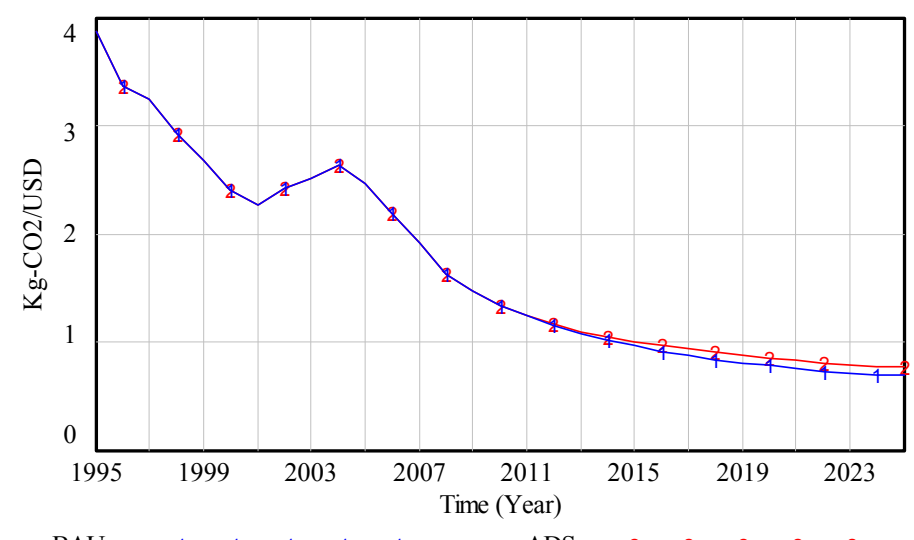

The performance indicates that GDP growth in ADS is lower than in BAU. From the model, this can be explained mainly by the introduction of the carbon tax which assumed to have a $1 \%$ negative influence to the GDP. However, it should be noted that the study [25] on which this assumption was based upon does not consider tax recycling. Should tax recycling be, it would produce much lower negative impact, thus a better performance would be expected.

China's per capita emission in the BAU scenario would reach up to 8.86 Ton- $\mathrm{CO}_{2} /$ capita in 2025 . The ADS scenario produces lower per capita emission at $8.12 \mathrm{Ton}-\mathrm{CO}_{2} /$ capita. In this regard, the ADS scenario is better by 0.74 Ton- $\mathrm{CO}_{2} /$ capita compared to BAU scenario. Figure 4 shows China's performance in term of per capita emission.

Figure 4. China's per capita emission.

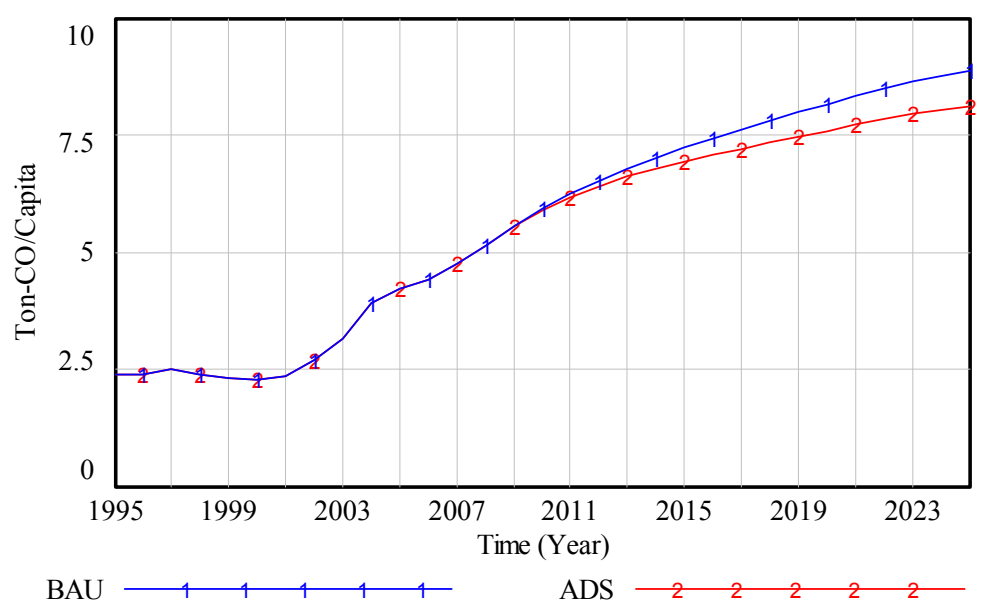

China's carbon intensity of energy in BAU scenario would be at 3.62 Ton- $\mathrm{CO}_{2} / \mathrm{TOE}$ in 2025. It is slightly lower than 2010 level at 3.59 Ton- $\mathrm{CO}_{2} / \mathrm{TOE}$. The ADS scenario produces lower carbon intensity of energy at 3.33 Ton- $\mathrm{CO}_{2} /$ capita in 2025. The ADS scenario is better by 0.29 Ton- $\mathrm{CO}_{2} / \mathrm{TOE}$ compared to the BAU scenario in 2025. Figure 5 shows China's carbon intensity of energy. 
Figure 5. China's carbon intensity of energy.

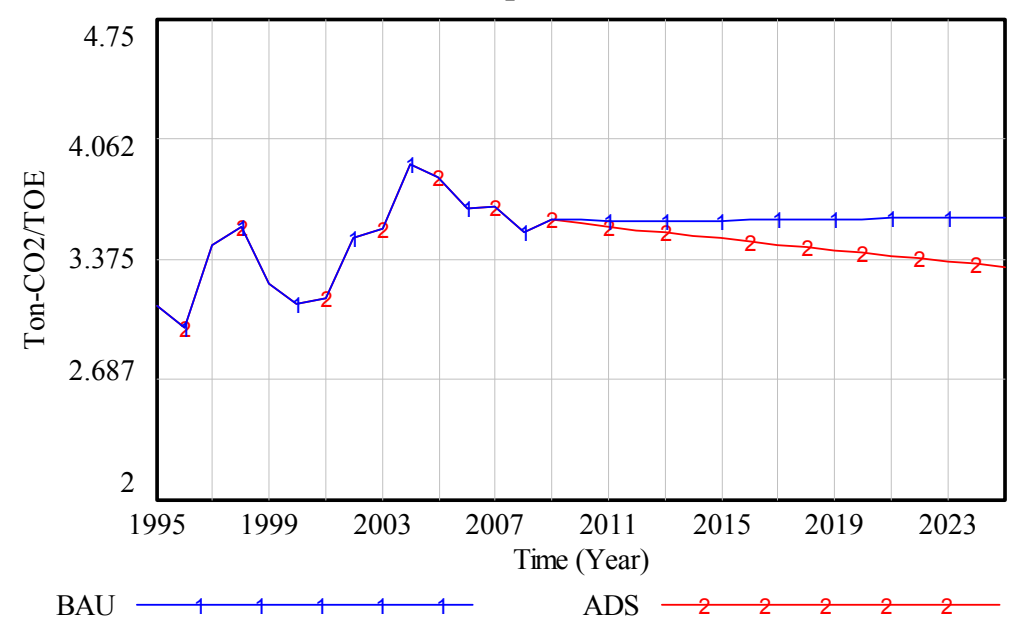

\subsubsection{Japan}

In the BAU scenario, Japan's $\mathrm{CO}_{2}$ emission would reach its peak in 2021 at $1204 \mathrm{Mton}-\mathrm{CO}_{2}$ and then decreasing to 1189 Mton- $\mathrm{CO}_{2}$ in 2025. It increased by $65 \mathrm{Mton}-\mathrm{CO}_{2}$ from 2008 level. The ADS closely resembles the BAU scenario because of the effect of the Fukushima catastrophe. Since the accident, Japan's $\mathrm{CO}_{2}$ emission is predicted to increase to a peak at $1201 \mathrm{Mton}-\mathrm{CO}_{2}$ in 2018. However, it would then decrease to $1,162 \mathrm{Mton}-\mathrm{CO}_{2}$ in 2025, which is $12 \mathrm{Mton}-\mathrm{CO}_{2}$ lower than in the BAU. Figure 6 shows the $\mathrm{CO}_{2}$ emission for Japan.

Figure 6. Japan's $\mathrm{CO}_{2}$ emission.

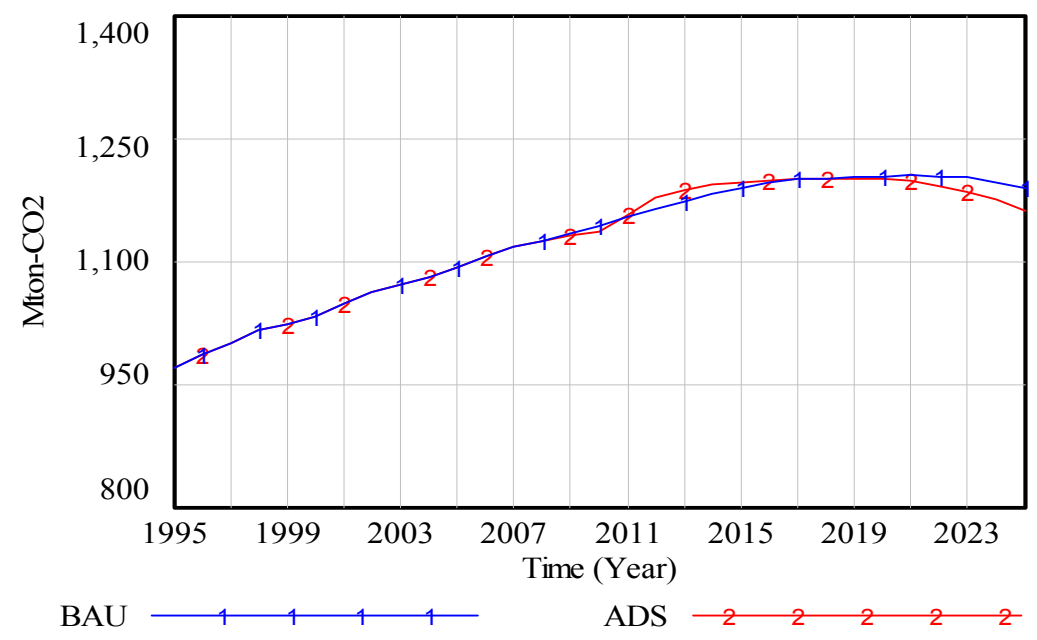

Japan's carbon intensity of economy in the BAU scenario would be at $0.227 \mathrm{Kg}-\mathrm{CO}_{2} / \mathrm{USD}$ in 2025 . The ADS scenario produces lower carbon intensity of economy at $0.212 \mathrm{Kg}-\mathrm{CO}_{2} / \mathrm{USD}$ in the same year. However, carbon intensity of economy in 2012 of ADS is higher than that of the BAU at 0.231 . Figure 7 shows Japan's carbon intensity of economy. 
Figure 7. Japan's carbon intensity of economy.

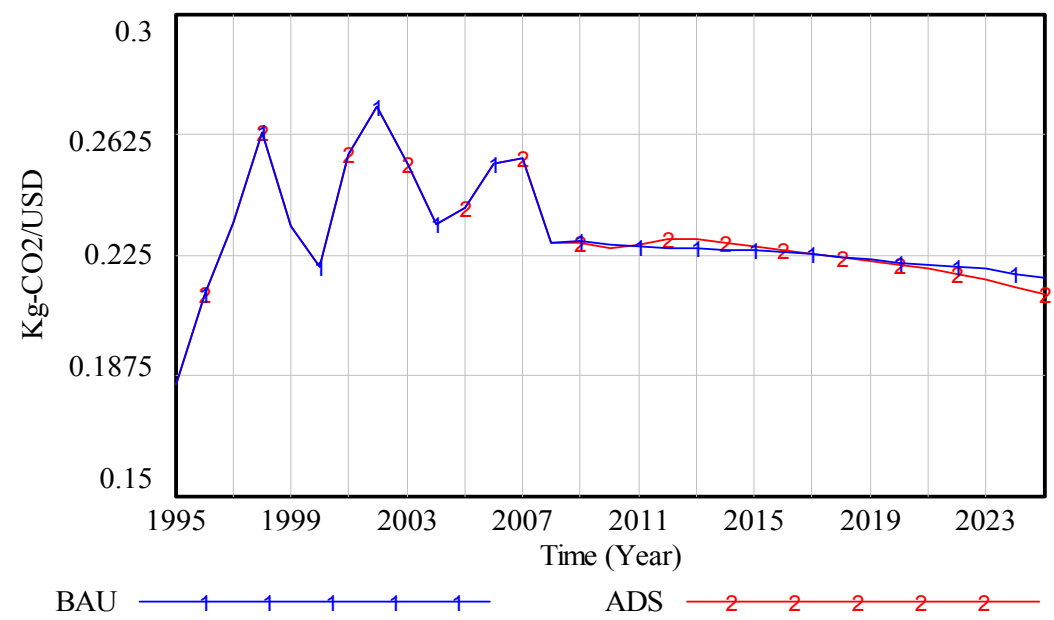

Japan's per capita $\mathrm{CO}_{2}$ emission in the BAU scenario would reach up to 9.75 Ton- $\mathrm{CO}_{2} /$ capita in 2025. The ADS produces lower per capita emission at 9.53 Ton- $\mathrm{CO}_{2} /$ capita in the same year. However, the ADS produces higher per capita $\mathrm{CO}_{2}$ emission compared to BAU scenario from 2011 until 2018. Figure 8 shows Japan's per capita emission performance.

Figure 8. Japan's per capita emission.

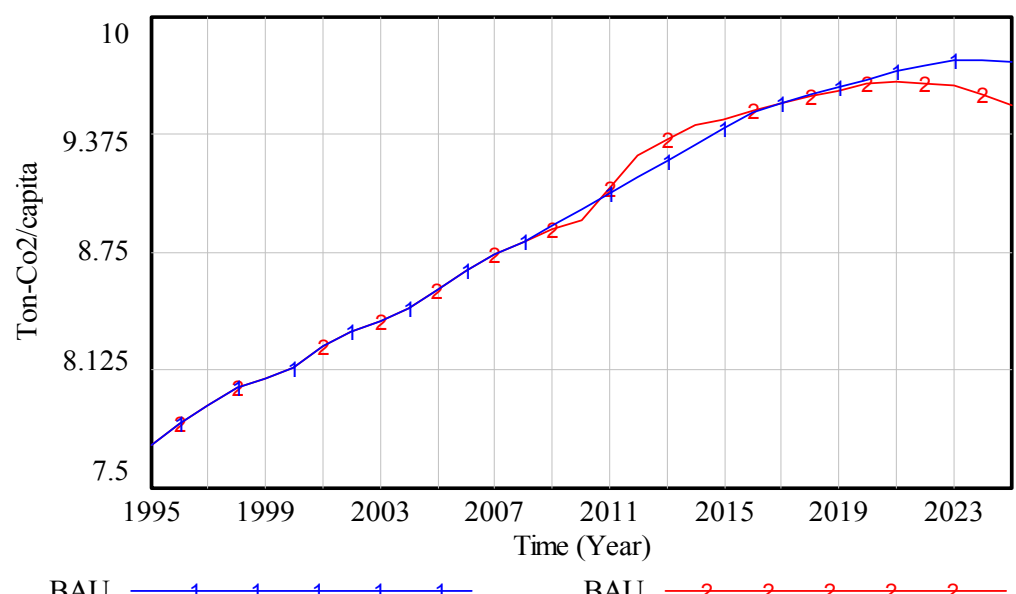

Japan's carbon intensity of energy in the BAU scenario would be at 1.86 Ton- $\mathrm{CO}_{2} / \mathrm{TOE}$ in 2025 . The ADS scenario produces a slightly higher carbon intensity of energy at 1.82 Ton- $\mathrm{CO}_{2} /$ capita. In 2013, the ADS scenario produces the highest carbon intensity of energy score of 2.20 Ton- $\mathrm{CO}_{2} /$ TOE. Figure 9 shows Japan's carbon intensity of energy. 
Figure 9. Japan's carbon intensity of energy.

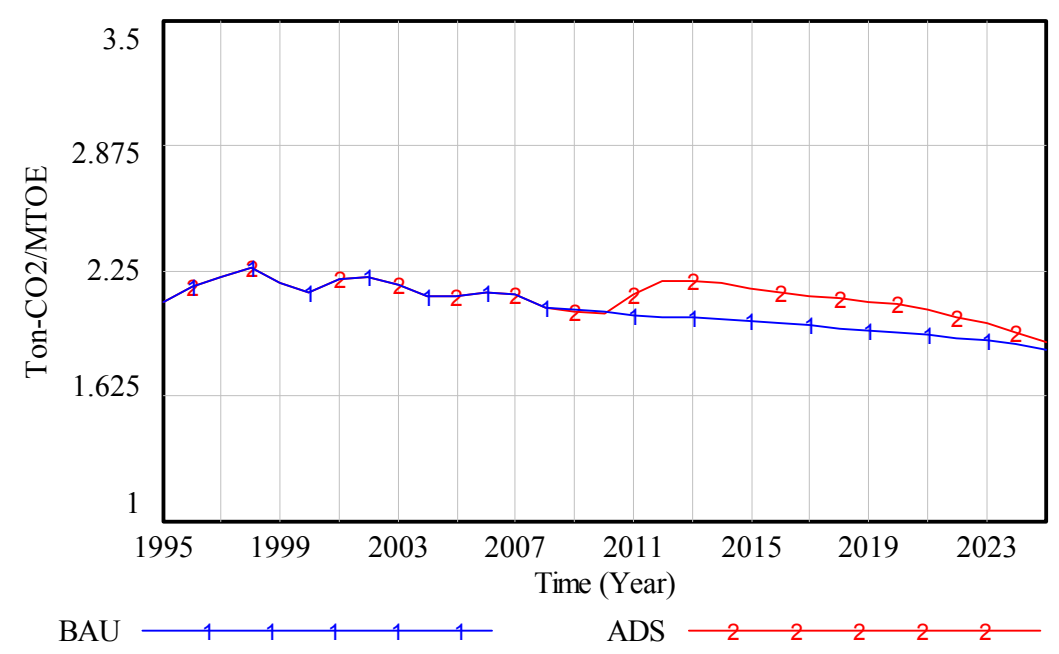

\subsubsection{Indonesia}

Indonesia's $\mathrm{CO}_{2}$ emission in the BAU scenario estimates it reaching up to 789 Mton- $\mathrm{CO}_{2}$ in 2025. The ADS scenario produces even higher $\mathrm{CO}_{2}$ emission, at $892 \mathrm{Mton}-\mathrm{CO}_{2}$ in 2025. In 2025, $\mathrm{CO}_{2}$ emission of the ADS scenario is 103 Mton- $\mathrm{CO}_{2}$ worse than that in the BAU scenario. Figure 10 shows the $\mathrm{CO}_{2}$ emission of Indonesia.

Figure 10. Indonesia's $\mathrm{CO}_{2}$ emission.

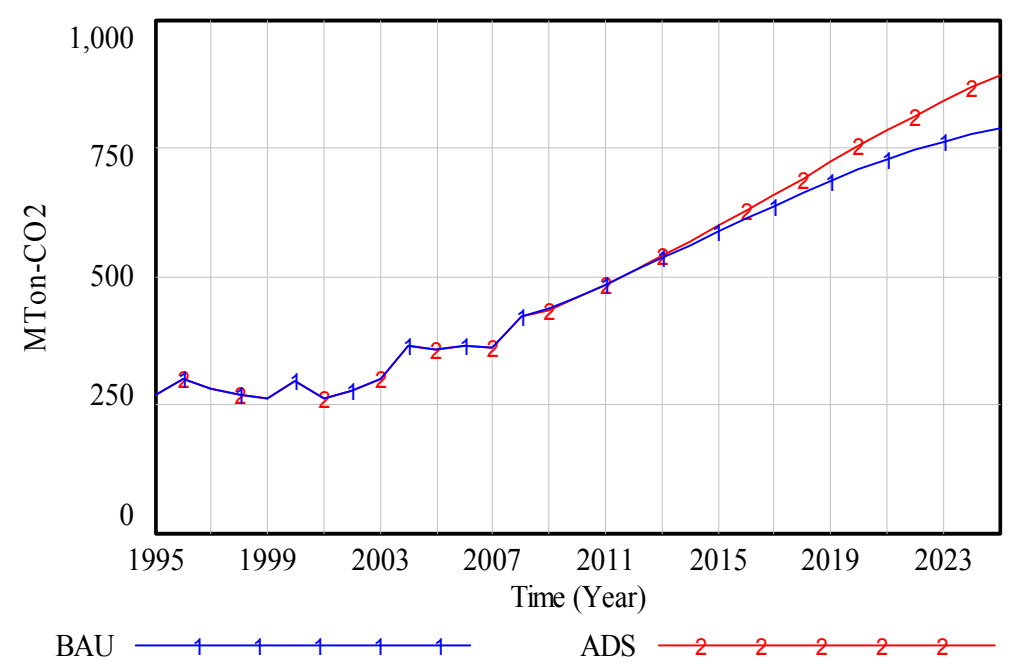

Indonesia's carbon intensity of economy in BAU scenario would be at $1.43 \mathrm{Kg}-\mathrm{CO}_{2} / \mathrm{USD}$ in 2025 . It decreases $0.05 \mathrm{Kg}-\mathrm{CO}_{2} / \mathrm{USD}$ compared to 2008 level. On the contrary, the ADS scenario produces higher carbon intensity of economy at $1.62 \mathrm{Kg}-\mathrm{CO}_{2} / \mathrm{USD}$. It increases $0.1 \mathrm{Kg}-\mathrm{CO}_{2} / \mathrm{USD}$ compared to 2008 level. Indonesia's carbon intensity of economy in 2025 in ADS worsens by $0.19 \mathrm{Kg}-\mathrm{CO}_{2} / \mathrm{USD}$ compare to BAU scenario, with respect to 2008 level. Figure 11 shows Indonesia's carbon intensity of economy. 
Figure 11. Indonesia's carbon intensity of economy.

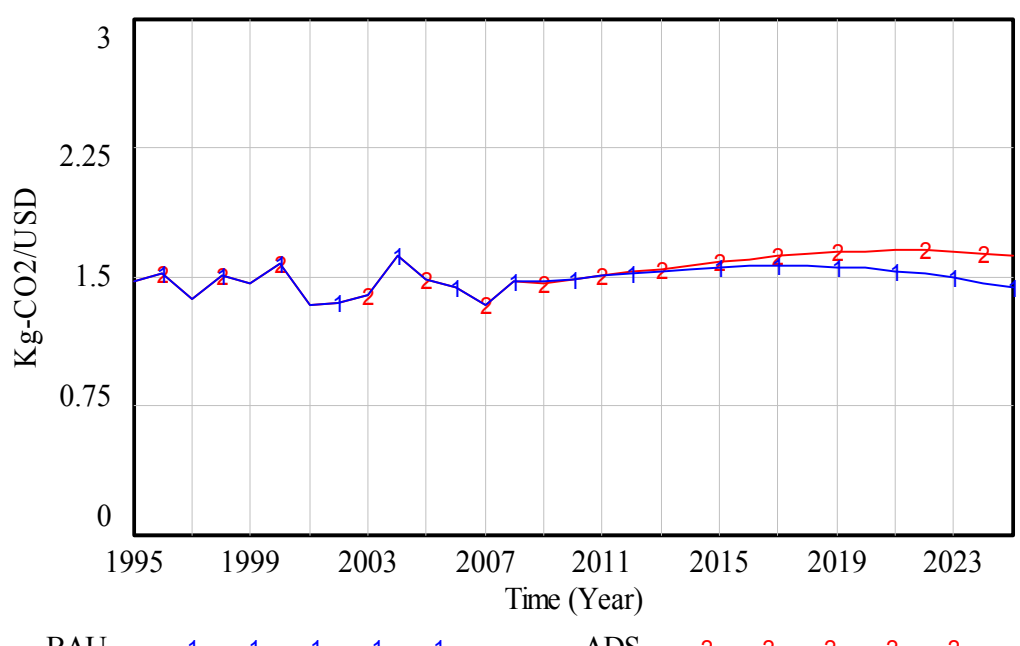

The performance indicates that GDP growth is lower than energy consumption growth. It can partly be attributed to the decrease of energy export. Indonesia energy exports account for approximately $11 \%$ of its GDP [14]. The decrease on energy export because of coal and gas domestic obligations contributes to a lower GDP growth.

Indonesia's per capita emission in the BAU scenario would reach up to 2.9 Ton- $\mathrm{CO}_{2} /$ capita in 2025 which is an increases of 1 Ton- $\mathrm{CO}_{2} /$ capita compared to 2008 level. The ADS scenario produces higher per capita emission at 3.2 Ton- $\mathrm{CO}_{2} /$ capita. It increases 1.4 Ton- $\mathrm{CO}_{2} /$ capita compared to 2008 level. The ADS in 2025 is 0.3 Ton- $\mathrm{CO}_{2} /$ capita worse than the BAU scenario. Figure 12 shows Indonesia's performance in term of per capita emission.

Figure 12. Indonesia's per capita emission.

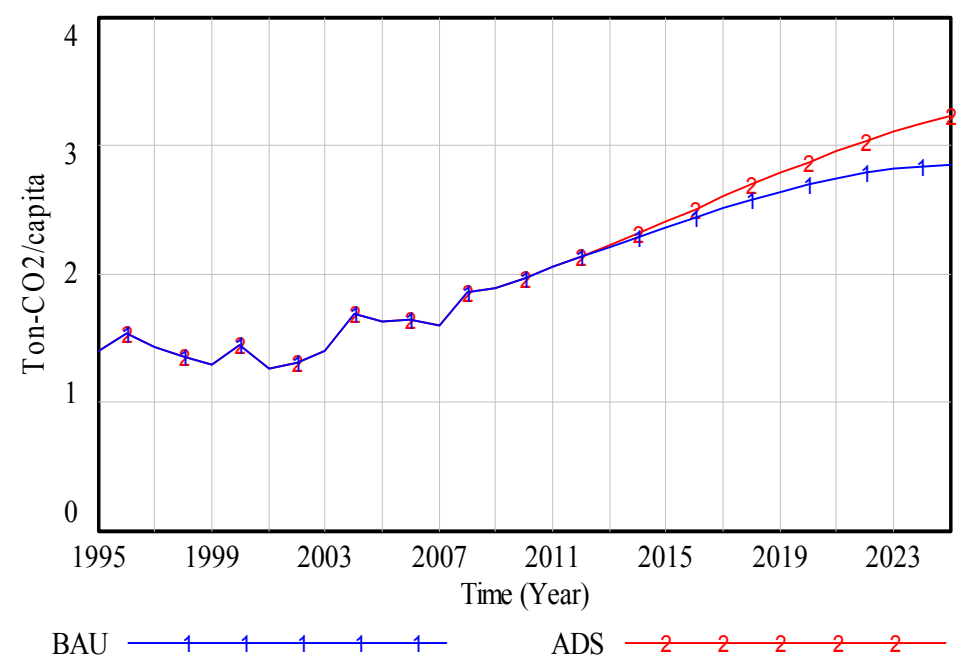

Indonesia's carbon intensity of energy in the BAU scenario would be at 2.9 Ton- $\mathrm{CO}_{2} / \mathrm{TOE}$ in 2025. The ADS scenario produces higher carbon intensity of energy at 3.1 Ton- $\mathrm{CO}_{2} /$ capita in 2025 . In 2025, the ADS scenario is worse by 0.2 Ton- $\mathrm{CO}_{2} / \mathrm{TOE}$ compared to that of the BAU. Figure 13 shows Indonesia's carbon intensity of energy. 
Figure 13. Indonesia's carbon intensity of energy

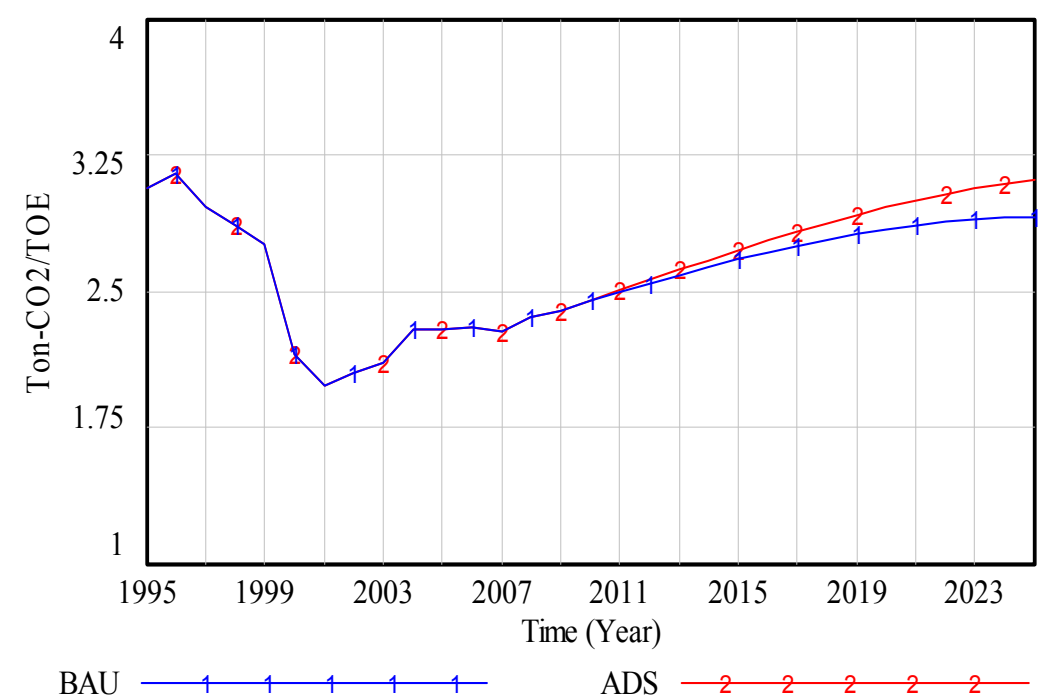

\subsection{Country Comparison}

In this section, results of the ADS scenarios are compared in terms of growth (nominal and proportion) with each country's performance from 2010 to 2025. The 2010 level is set as the reference point at 0 .

\subsection{1. $\mathrm{CO}_{2}$ emission}

$\mathrm{CO}_{2}$ emission of China in 2025 is by far the largest at 4227.4 Mton- $\mathrm{CO}_{2}$ compared to Japan and Indonesia. However, Indonesia's growth is the fastest with a $111.7 \%$ increase from 2008 level, and Japan's growth is the lowest in both amount and proportion. Figure 14 shows $\mathrm{CO}_{2}$ emission growth of the countries.

Figure 14. $\mathrm{CO}_{2}$ emission growth between 2010 and 2025 in the ADS scenario.

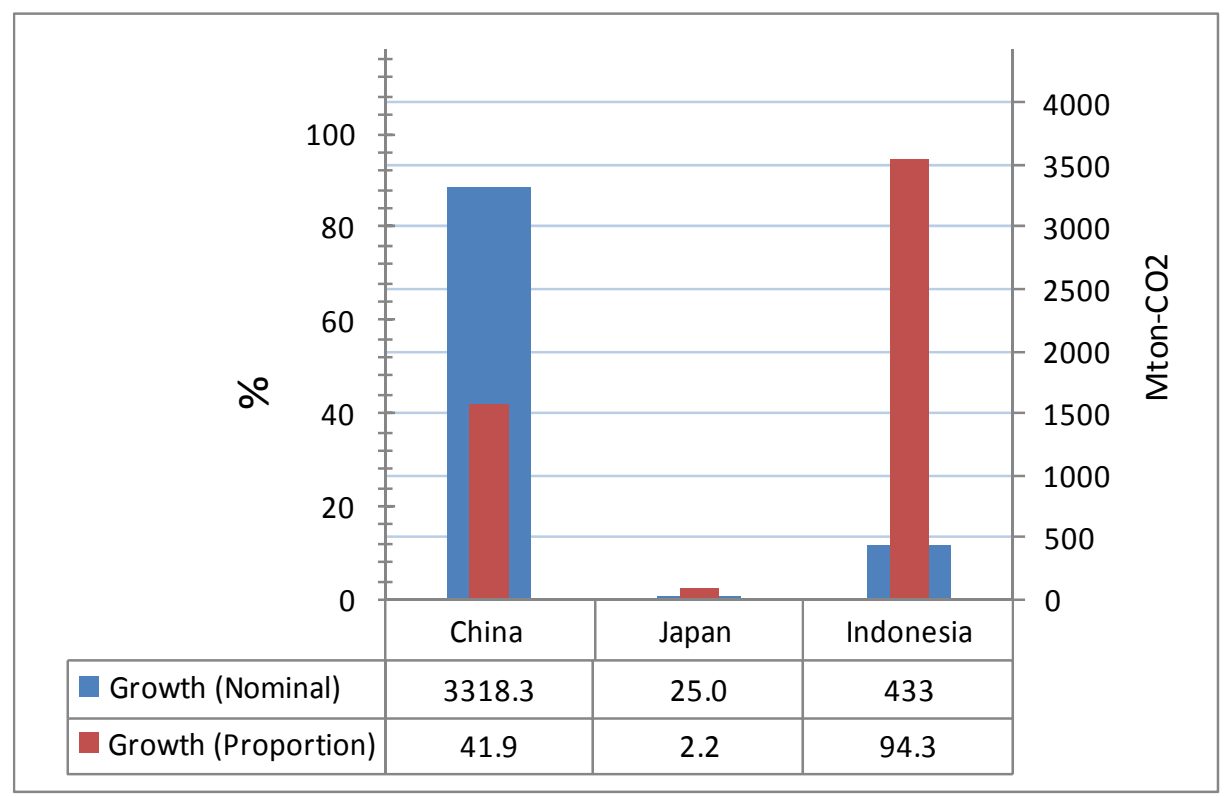




\subsubsection{Carbon Intensity of Economy}

China performance in 2025 is also by far the largest in term of carbon intensity of economy with a decrease at $0.86 \mathrm{Kg}-\mathrm{CO}_{2} / \mathrm{USD}$ or $52.8 \%$ compared to Japan and Indonesia. On the contrary, Indonesia's carbon intensity of economy is worsening by increasing $0.1 \mathrm{Kg}-\mathrm{CO}_{2} / \mathrm{USD}$ or $9.6 \%$ compared to the 2008 level. Meanwhile, Japan's carbon intensity of economy is decreased by 0.02 or $10 \%$, as compared to the 2008 level. Figure 15 shows the carbon intensity of economy of all three countries.

Figure 15. Growth of carbon intensity of economy between 2010 and 2025 in the ADS scenario.

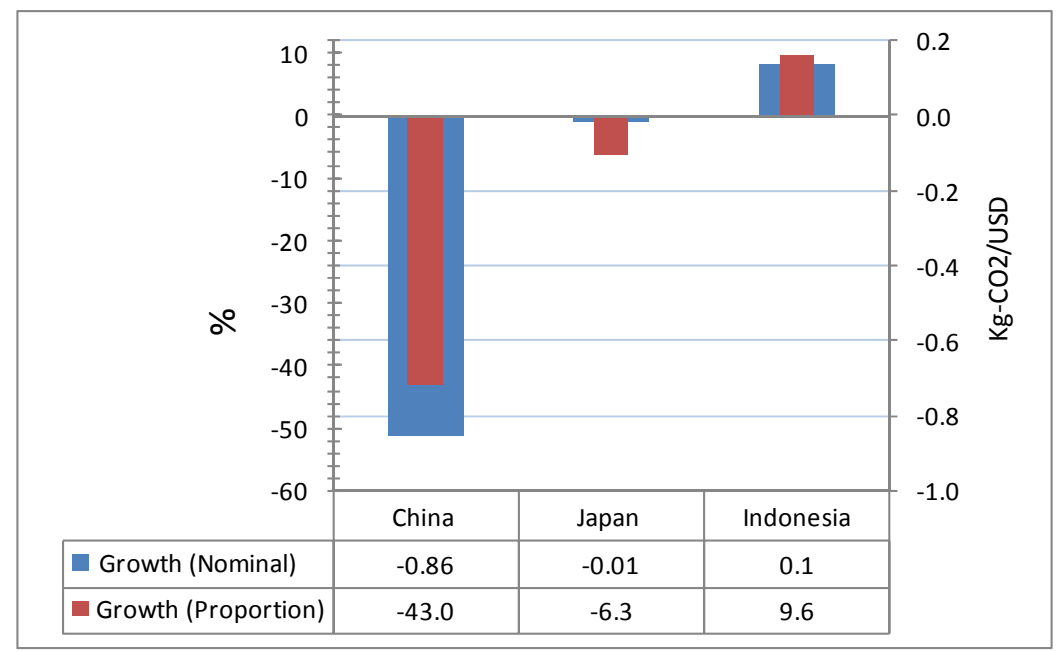

\subsubsection{Per Capita Emission}

China's performance in 2025 is the largest in terms of per capita emission with an increase of 3 Ton- $\mathrm{CO}_{2} /$ capita or $58.7 \%$ compared to Japan and Indonesia. However, Indonesia's per capita emission as the sharpest increase at $74 \%$ or 1.4 Ton- $\mathrm{CO}_{2} /$ capita compared to its 2008 level. Japan's per capita emission is increased by 0.4 Ton- $\mathrm{CO}_{2} /$ capita or $4.9 \%$ compared to its 2008 level. Figure 16 shows the per capita emission growth of the countries.

Figure 16. Growth of per capita emission between 2010 and 2025 in the ADS scenario.

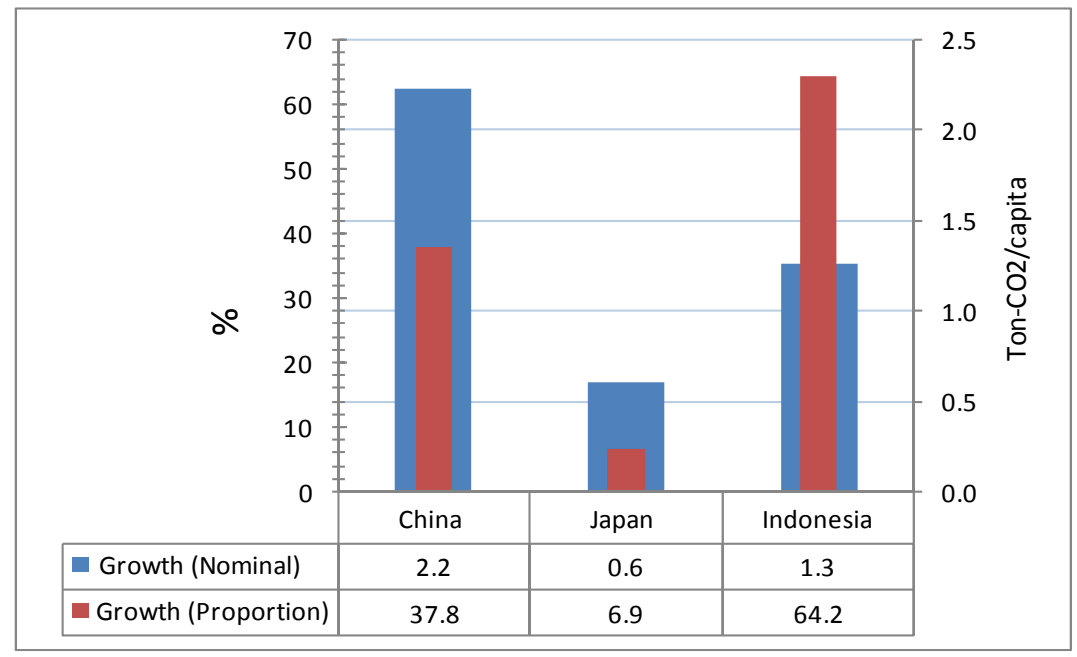




\subsubsection{Carbon Intensity of Energy}

Japan's performance in 2025 is the largest and fastest in terms of carbon intensity of energy with a decrease at 0.24 Ton- $\mathrm{CO}_{2} / \mathrm{TOE}$ or $11.4 \%$ compared to China and Indonesia. On the contrary, Indonesia's carbon intensity of energy worsens and increases by as much as 0.8 Ton- $\mathrm{CO}_{2} / \mathrm{TOE}$ or $31.8 \%$ compared to its 2008 level, while China's carbon intensity of energy is decreased by 0.2 Ton- $\mathrm{CO}_{2} / \mathrm{TOE}$ or $5.6 \%$ compared to its 2008 level. Figure 17 shows the carbon intensity of energy performance of the three countries.

Figure 17. Growth of carbon intensity of energy between 2010 and 2025 in the ADS.

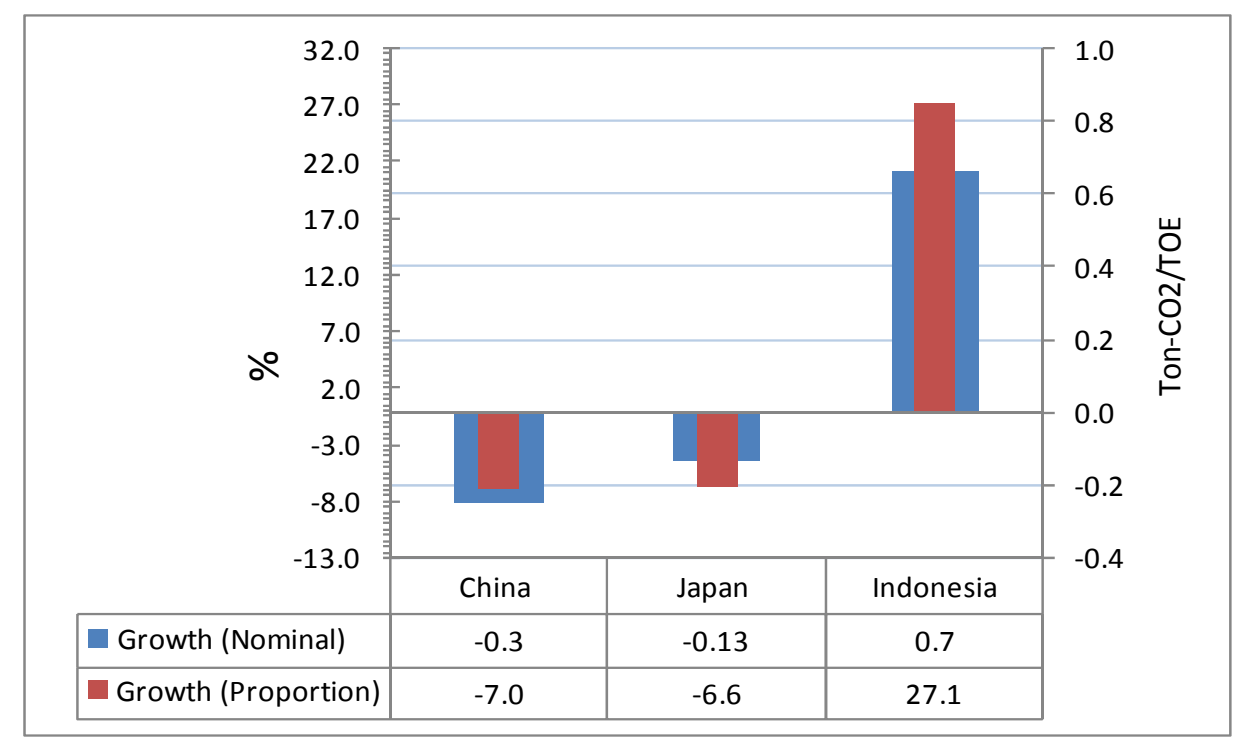

\section{Discussion}

Provided that fossil energy resources are abundant, improving energy security by increasing fossil energy availability is the preferred policy for Indonesia and China. However, this strategy contradicts the environmental aspect of energy security.

Indonesia's policy of meeting energy demands by redirecting a significant portion of its coal and gas production to the domestic market would increase the domestic availability of both energy sources. Of course, the policy will not have any effect on global $\mathrm{CO}_{2}$ emissions because coal and gas will still be utilized elsewhere when exported; however, the policy has a significant effect on $\mathrm{CO}_{2}$ emission growth within the country. The simulation results suggest that this policy has much stronger negative impact on Indonesia's performance compared to the positive impacts of other energy policies, such as renewable energy introduction and energy efficiency and conservation policies. The increased domestic supply of fossil energy is also followed by a decrease in the fossil energy export contribution to GDP, increasing the economic reliance on gas and coal, and leading to lower quality performance in the carbon intensity of economy.

In China's case, its reliance on coal makes it very difficult to decrease its $\mathrm{CO}_{2}$ emissions. In fact, the policy of capping coal utilization in 2015 is too great a challenge, if it is even possible at all. In addition, the simulation results suggest that the value set for the cap is rather superfluous as the cap is not likely to be reached. It is likely that China's coal utilization will still be increasing at that time. 
In both cases, technological intervention, such as the adoption of Carbon Capture and Storage (CCS) technology, may play a key role by dramatically reducing the $\mathrm{CO}_{2}$ emission levels from coal utilization, provided that the cost of CCS technology is competitive in the near future.

Another important element of energy supply is renewable energy, which allows electricity production to shift away from fossil energy and thus mitigates $\mathrm{CO}_{2}$ emissions. Because nuclear energy remains controversial in many countries, such as Indonesia, biomass, hydro, geothermal, wind and solar energy are generally accepted as alternatives to fossil energy sources.

China has clearly put enormous efforts towards using these alternative sources. Its ambitious policies for introducing renewable and nuclear energy may significantly slow the growth of $\mathrm{CO}_{2}$ emissions because cleaner energy utilization will increase, while the coal utilization rate will remain constant.

In contrast, the utilization of renewable energy is very limited in Indonesia. Even policy measures only target moderate improvements. This is contrary to the fact that Indonesia's biomass, solar and geothermal energy potentials are substantial [17]. Intensifying the development of these energy resources by, for example, building biomass electric plants, solar concentration farms and more geothermal plants, is important to improve Indonesia's energy supply as well as accelerate its transition from fossil energy. However, these developments require large investments, and policies that support private involvement in developing these energy resources are enormously important.

Regarding demand, energy efficiency plays an important role in reducing energy consumption and, therefore, $\mathrm{CO}_{2}$ emissions. Japan has been and continues to be the world leader in this regard. The simulation results show that the carbon intensity of the energy of Japan would still be the lowest among the three countries and continue to decrease in spite of Japan's saturated economic growth and the Fukushima events, although the rate has slowed. In addition, its per capita $\mathrm{CO}_{2}$ emission rate is also increasing at the lowest rate, even with its decreasing population, which also suggests higher energy efficiency per capita.

The largest energy consumption sector in all three countries is the industrial sector $[14,18,39]$. However, efficiency has greatly improved in this sector. Conversely, the transportation, residential and commercial sectors may still have plenty of room for improvements in efficiency. Provided that the "rebound-effect" [40] is absent, higher efficiency in these sectors may contribute significantly to reductions in fossil fuel and electricity consumption in these countries, eventually leading to lower $\mathrm{CO}_{2}$ emissions.

As with the supply side, renewable energy consumption plays an important role in improving the carbon intensity of energy. As more electricity from renewable energy is consumed, less fossil energy is used to produce electricity and $\mathrm{CO}_{2}$ emissions are reduced. In this regard, China's simulation results indicate an improved carbon intensity of energy, which partly represents a shift from fossil energy use towards renewable energy use.

For Indonesia, intensifying the transfer of renewable energy and energy efficient technology, such as solar PV, or energy efficient vehicles and appliances from advanced countries such as Japan, may improve Indonesia's performance. However, this transfer faces financial difficulties and the lack of production capacity $[18,41]$. Therefore, to gain a high adoption rate, it must be followed by adequate adoption policies, i.e., incentives and capacity building. 
The three countries' commitments to the Cebu declaration are reflected in the simulation results. The Cebu declaration states that one of the goals for East Asia energy security is to "Mitigate greenhouse gas emission through effective policies and measures, thus contributing to global climate change abatement." Considering the performance of the countries, it is clear that, among the three, Indonesia is least likely to keep its commitment toward this goal. Conversely, the performances of Japan and China show a likelihood of achieving the goal.

In a larger context, under the United Nation's Cancun agreement, the three countries pledged to reduce their $\mathrm{CO}_{2}$ emission. Indonesia pledged a target to cut its total $\mathrm{CO}_{2}$ emission (including land use, land use change and forestry) by $26 \%$ below the BAU scenario by 2020 . Indonesia is a major carbon dioxide emitter due to its extensive land use change activities such as deforestation [42]. One purpose of deforestation is to produce palm oil for biofuel energy. Although $\mathrm{CO}_{2}$ emission tradeoffs between biofuel energy consumption and deforestation are not covered in this study, it is an important consideration in judging Indonesia's total carbon performance, which needs further investigation. On the whole, it is likely that Indonesia's energy sector would not contribute to this pledge achievement. Japan pledged to cut $20 \%$ of its $\mathrm{CO}_{2}$ emission by 2020 relative to its 1990 statistics. It is unlikely that the pledge can be realized, and a new direction will likely to be proposed. On the other hand, China is on its way to fulfill its pledge for $40 \%$ to $45 \%$ reduction of carbon intensity of economy by 2020 relative to its 2005 numbers.

\section{Conclusion}

A model has been developed to simulate the future environmental performances of China, Japan and Indonesia from an energy security perspective for the period between 2008 and 2025. Two types of scenarios were developed for the simulation. The BAU scenario is used as a reference scenario, which reflects the continuation of energy policies in place before 2009. The ADS is used to estimate the progression of environmental performance in the future and reflects implementation of the latest energy supply policies. In addition, carbon tax policy is also considered in the scenarios.

It was found that the $\mathrm{CO}_{2}$ emissions of all countries are increasing until 2025 for all scenarios. In the ADS, Japan has the best performance with the smallest increase in both growth and amount of $\mathrm{CO}_{2}$ emissions, in spite of the Fukushima accident. China is the largest carbon dioxide emitter, but its emission growth is slowing. Conversely, Indonesia's $\mathrm{CO}_{2}$ emissions rate is growing the fastest. In terms of carbon intensity of economy, China's performance is the best regarding the amount and speed. Japan's performance is insignificant compared to China's but is still much better than that of Indonesia. Indonesia's performance is the poorest and its carbon intensity of economy increases instead of decreasing. In terms of per capita $\mathrm{CO}_{2}$ emission performance, China's performance is characterized by a large increase. However, Indonesia still has the fastest growth. Japan's performance is best for this indicator. In terms of carbon intensity of energy, Japan's performance is the best. On the other hand, Indonesia's is the worst because it has both the largest and fastest increase of energy consumption and emissions. At the same time, China's performance is better than Indonesia's, but smaller and slower than Japan's.

Despite the recognition of the Cebu declaration as a common platform to move forward towards improving regional energy security, the countries' different characteristics cause each to have its own 
priorities, rendering the declaration ineffective. After all, the declaration does not impose any obligations on the countries to reach their goals. Thus, this study recognizes the need to advance the declaration towards a more obligatory commitment with clear $\mathrm{CO}_{2}$ emission reduction targets.

\section{Acknowledgments}

This paper publication is supported in part by Keio University-Global Centre of Excellence (Keio GCOE-H10) program and the Supporting Organization for Research of Industrial Structure, Japan. The authors are very grateful for the supports.

\section{Conflict of Interest}

The authors declare no conflict of interest.

\section{References and Notes}

1. IEA. Energy Security and Climate Change: Assessing Interactions; International Energy Agency: Paris, France, 2007.

2. APERC. A Quest for Energy Security in the 21st century; Asia Pacific Energy Research Centre-Institute of Energy Economics: Tokyo, Japan, 2007.

3. IEA. Contribution of Renewables to Energy Security; International Energy Agency: Paris, France, 2007.

4. ASEAN. Cebu Declaration on East Asia Energy Security; ASEAN secretariat: Jakarta, Indonesia, 2007.

5. East Asian Summit (EAS) is a regional forum which attended by ASEAN +6 countries. It includes all ASEAN countries plus China, Japan, Korea, India, Australia and New Zealand. Recently United States and Russia are also joining the forum.

6. Ozeki, H. Development of De Facto Economic Integration in East Asia. In Deepening Economic Integration in East Asia: The ASEAN Economic Community and Beyond; Soesastro, H., Ed.; Economic Research Institute for ASEAN and East Asia: Jakarta, Indonesia, 2008.

7. ADB. Key Indicators for Asia and Pacific 2010; Asian Development Bank: Mandaluyong City, Philippines, 2010.

8. ADB. Asian Development Outlook 2011; Asian Development Bank: Mandaluyong City, Philippines, 2011.

9. World Bank. World Development Indicator and Global Development Finance. Available online: http://databank.worldbank.org (accessed on 23 August 2012).

10. Nasir, A.; Ali, T.M.; Shahdin, S.; Rahman, T.U. Technology achievement index 2009: Ranking and comparative study of nations. Scientometrics 2011, 87, 41-62.

11. IEEJ. APEC Energy Database. 2011. Retrieved from the Institute of Energy Economics Japan. Available online: www.ieej.or.jp (accessed on 2 February 2011).

12. Leung, G.C.K. China's energy security: Perception and reality. Energ. Pol. 2011, 39, 1330-1337.

13. EIA. International energy statistics. Energy Information Administration U.S. Department of Energy. 2011. Available online: http://www.eia.gov/ (accessed on 20 February 2011). 
14. MOIAC. Statistical Handbook of Japan; Ministry of Internal Affairs and CommunicationsStatistics Bureau: Tokyo, Japan, 2010.

15. BPS. Pertumbuhan Ekonomi Indonesia; Biro Pusat Statistik: Jakarta, Indonesia, 2011.

16. BAPENNAS-BPS. Proyeksi Penduduk 2000-2025; Badan Perencanaan Nasional—Biro Pusat Statistik: Jakarta, Indonesia, 2005.

17. UNDP. Human Development Report 2001: Making New Technologies Work for Human Development; United Nation Development Program, Oxford University Press: New York, USA, 2001.

18. BPPT. Outlook Energy Indonesia 2010; Badan Pengkajian and Penerapan Teknologi-Press: Jakarta, Indonesia, 2010.

19. Vivoda, V. Evaluating energy security in the Asia-Pacific region: A novel methodological approach. Energ. Pol. 2010, 38, 5258-5263.

20. Sovacool, B. Evaluating energy security in the Asia Pacific: Towards a more comprehensive approach. Energ. Pol. 2011, 39, 7472-7479.

21. Sovacool, B.K.; Mukherjee, I.; Drupady, I.M.; D’Agostino, A.L. Evaluating energy security performance from 1990 to 2010 for eighteen countries. Energy 2011, 36, 5846-5853.

22. Prambudia, Y.; Todo, Y.; Nakano, M. Energy Security of Indonesia: System Dynamic Modelling and Policy Simulation. In Proceedings of the 10th Global Conference on Flexible Systems Management: Designing for Flexibility and Security for The Future, Yokohama, Japan, 2010.

23. United Nations. UN Data. Statistics. Available online: http://data.un.org (accessed on 2 March 2011).

24. UNIDO. Capability Building for Catching-Up: Historical, Empirical and Policy Dimensions; United Nations Industrial Development Organization-United Nations: Vienna, Austria, 2005.

25. KPMG. China's 12th Five-Year Plan: Energy; KPMG Advisory China Limited: Beijing, China, 2011.

26. Lu, C.; Tong, Q.; Liu, X. The impact of carbon tax and complementary policies on Chinese economy. Energ. Pol. 2010, 38, 7278-7285.

27. METI. The Strategic Energy Plan of Japan: Meeting Global Challenges and Securing Energy Futures; Ministry of Economy Trade and Industry: Tokyo, Japan, 2010.

28. Toyoda, M. The Future of Energy Policy Agenda after the Great East Japan Earthquake; Institute of Energy Economic Japan (IEEJ): Tokyo, Japan, 2011.

29. IPCC. Carbon Dioxide Capture and Storage; Intergovernmental Panel on Climate Change: Cambridge, UK and New York, USA, 2005.

30. Sakata, Y. The Economic Impact of Carbon Tax in Japan. In Workshop on Environment and Energy (WEE2006), Osaka, Japan, 2006.

31. MoEMR. Blueprint Pengelolaan Energy Nasional 2006-2025; Ministry of Energy and Mineral Resources: Jakarta, Indonesia, 2006

32. MoEMR. Rancangan Blueprint Pengembangan Energi Baru Terbarukan dan Konservasi Energi; Ministry of Energy and Mineral Resources: Jakarta, Indonesia, 2010.

33. MoEMR. Persentase Minimal Penjualan Batubara Dalam Negeri Tahun 2011; Ministry of Energy and Mineral Resources: Jakarta, Indonesia, 2010. 
34. MoEMR. Kontrak Gas Domestik 2011 Mencapai 57 Persen; Ministry of Energy and Mineral Resources: Jakarta, Indonesia, 2011.

35. BATAN. Sejarah Singkat Program Pembangunan PLTN di Indonesia. Badan Tenaga Nuklir Nasional. Available online: http://www.batan.go.id/ppen/tu/SejarahPLTN.htm (accessed on 3 January 2011).

36. MoF. Ministry of Finance Green Paper: Economic and Fiscal Policy Strategies for Climate Change Mitigation in Indonesia; Ministry of Finance and Australia Indonesia Partnership: Jakarta, Indonesia, 2009.

37. Yusuf, A.; Resosudarmo, B. On the Distributional Effect of Carbon Tax in Developing Countries: The Case of Indonesia. In Working Paper in Economics and Development Studies no. 20075; Padjadjaran University: Bandung, Indonesia, 2007.

38. IEA. $\mathrm{CO}_{2}$ Emissions from Fuel Combustion: Highlights; International Energy Agency: Paris, France, 2010.

39. APERC. Understanding Energy in China; Asia Pacific Energy Research Centre: Tokyo, Japan, 2008.

40. Greening, L.A.; Greene, D.L.; Difiglio, C. Energy efficiency and consumption-The rebound effect-A survey. Energ. Pol. 2000, 28, 389-401.

41. TERI. Capacity Building for Technology Transfer in the Context of Climate Change; Tata Energy Research Institute: New Delhi, India, 1997.

42. DNPI, Dewan Nasional Perubahan Iklim (National Council for Climate Change); United Nations Framework Convention on Climate Change (UNFCC). National Economic, Environment and Development Study (NEEDS) for Climate Change: Indonesia Country Study; Dewan Nasional Perubahan Iklim: Jakarta, Indonesia, 2009.

(C) 2012 by the authors; licensee MDPI, Basel, Switzerland. This article is an open access article distributed under the terms and conditions of the Creative Commons Attribution license (http://creativecommons.org/licenses/by/3.0/). 